\title{
Effect of Cold and Hot Temperature on Behavioral and Selected Physiological Measures of Uromastyx aegyptius (Agamidae)
}

\author{
A.A. EI-Banna and A.M. Al- Johany
}

Department of Zoology, College of Science, King Saud University, P.O.Box 2455, Riyadh 11451, Saudi Arabia, Email: ajohany@ksu.edu.sa.
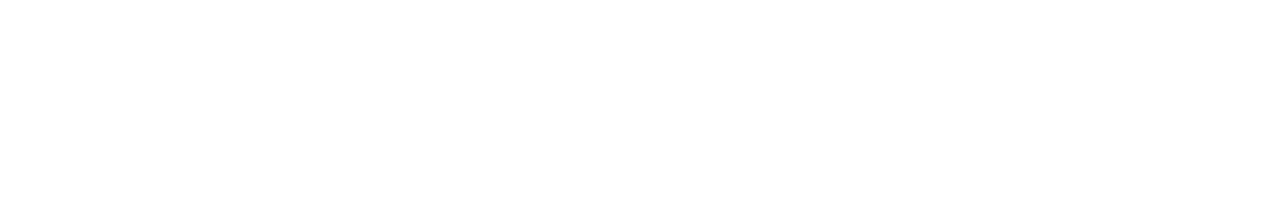

خلاصدة : تم ـت درلسة اللستجابلت للسلوكية والفسيولوجية والكيميلحيوية لدرجلت الحرارة الباردة والعالية للضب المصري . هromastyx aegyptius

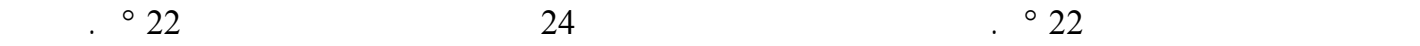

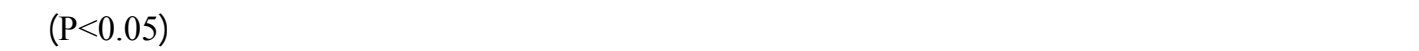

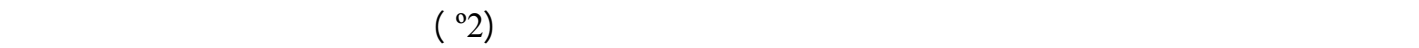

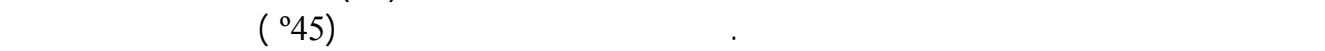

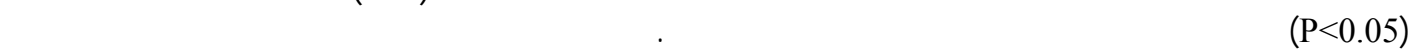

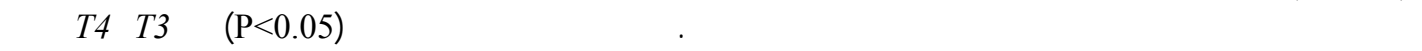

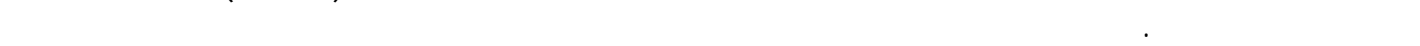

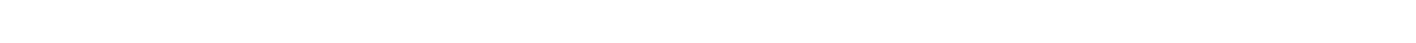

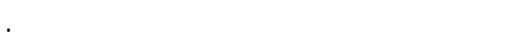

ABSTRACT: The behavioral, physiological and biochemical response to low $\left(2{ }^{\circ} \mathrm{C}\right)$ and high $\left(45^{\circ} \mathrm{C}\right)$ temperatures was studied in Uromastyx aegyptius. Twelve animals were divided into two experimental groups. A third control group was kept at $22^{\circ} \mathrm{C}$. All animals in the cooling, warming, and control groups were allowed a period of 24 hours for adjustments at $22^{\circ} \mathrm{C}$. Blood samples were collected from each animal when body temperature reached the corresponding levels. The results showed a significant $(\mathrm{P}<0.05)$ decrease in blood glucose and cholesterol levels during cooling $\left(2^{\circ} \mathrm{C}\right)$. This reduction in extracellular fluid substrates reflects an increase in cellular uptake of these substrates. Warming $\left(45^{\circ} \mathrm{C}\right)$ resulted in a significant $(\mathrm{P}<0.05)$ increase in total proteins, urea, and uric acid. These later changes could be attributed to an increase in the evaporative water loss, particularly due to the increased observed panting, and the associated reduction in plasma volume. There were no significant $(\mathrm{P}>0.05)$ changes in $\mathrm{T} 3$ and $\mathrm{T} 4$, during cooling nor during warming. The results of this study suggest augmentation of anaerobic metabolism of the U.aegyptius during cooling as evident by reduction in blood glucose levels. Furthermore, shift of glucose from the extracellular to the intracellular fluids demonstrates anticipation against potential freezing in order to protect the animal from intracellular freezing.

KEYWORDS: Metabolism, Temperature; Behaviour; Blood Constituents; Plasma; Uromastyx; Lizard.

\section{Introduction}

$\mathbf{T}$

The spiny tailed lizard Uromastyx aegyptius is the largest agamid lizard and is widespread in Arabia (Arnold, 1986). It is a diurnal animal and becomes active during the warm part of the day. Many terrestrial ectotherms, like the U. aegyptius, have a considerable capacity for behavioral and physiological thermoregulation (Bartholmew, 1981). Although many ectotherms are 


\section{A.A. EL-BANNA and A.M. AL-JOHANY}

physiologically adapted to survive at low ambient temperatures, terrestrial ectotherms are particularly susceptible to freezing, and there are a variety of strategies that enable ectothemic animals to survive freezing conditions (Hew et al. 1986). Ectotherms exposed to high temperature can either attempt to regulate their body temperature below the air temperature or rely on biochemical adaptation for tolerance of high body temperature (Cossins and Bowler, 1987).

Additionally, high temperature causes proteins to unfold and hence enzymes protein can no longer function. However, heat shock protein (HSP) response by programming cellular activities that bind and help mutated protein to restore their shape. Ulmasov, et al., (1992) and Zatespina, et al., (2000) found that HSP plays a major role in the cellular response during heat stress. Their findings also included a positive relationship between HSP and the magnitude of thermotolerance among lizard species. We thought that HSP dynamic relates to total plasma protein, and related measures such as albumin, and globulin. Thyroid hormones are involved indirectly in thermoregulation by increasing metabolic rate and subsequently heat production. Despite this, controversy exist regarding the initial calorigenic effects of thyroxin. Sinha and Choubey (1981) reported a positive relationship between thyroid activity and environmental temperature in $U$. hardwickii lizards. As thyroxin enhances cellular absorption of glucose and also influence plasma cholesterol, we included these measures in our study.

Thermoregulatory adjustment of the lizards are behavioral or physiological changes to deflect the body temperature from environmental heat loads (Firth and Belan, 1998). Measurements of blood composition are commonly used to assess the way in which the environment affects the physiology of animals. Therefore the objective of the present study was to investigate some aspects of physiological and biochemical responses of the U.aegyptius when exposed to low and to high temperatures.

\section{Materials and methods}

Eighteen $U$. aegyptius (mean wt. 760 gms) were collected from the field (Rumah and Haradh townships around Riyadh city, Saudi Arabia). The animals were housed in an open vivarium ( $2 \mathrm{~m} \mathrm{x}$ $1 / 4 \mathrm{~m}$ ) with overhead heat and light lamps with timer control set at 12:12 for light and dark periods and kept at a constant air temperature of $22^{\circ} \mathrm{C}$ (room temperature). The animals were then divided into three groups ( 6 animals in each) of matched body weight.

Blood samples were collected from animals in the control group at $22^{\circ} \mathrm{C}$. Animals in the two experimental groups were exposed to the low and high temperatures, as described below. Body temperature was maintained at $45^{\circ} \mathrm{C}$ for the warm group and $2{ }^{\circ} \mathrm{C}$ for the cold group for $24 \mathrm{hrs}$ and $48 \mathrm{hrs}$, respectively. Blood samples were collected at the end of exposure time. All blood samples were collected by cardiac puncture method using vacutainers. The vials were kept at room temperature for one to two hours, then, centrifuged at $3000 \mathrm{rpm}$ for 10 minutes to separate the plasma which was stored at $-20^{\circ} \mathrm{C}$ for later analysis.

\subsection{Cooling procedure: exposure to low temperature}

All animals of the second group were placed in Plexiglas chamber. A YSI model 423 thermocouple temperature probe was inserted $2 \mathrm{~cm}$ into the cloaca of the animal and held tight with a tape on the tail of the animal. The probe was attached to an YSI telethermometer (Model 44) in conjunction with a Omni scribe chart recorder to monitor the internal body temperature of the animal. Each animal was placed on a multiple benched mini-cold lab model 2203 (LKB-Produkter $\mathrm{AB}$ ), and the temperature was set to $2^{\circ} \mathrm{C}$. Animals were left in this environment for 48 hours before taking the blood sample.

\subsection{Warming procedure: exposure to the high temperature}

The same probe and recording instruments were tied to the animals while exposing them to the high temperature. A Plexiglas chamber animal was fixed in a water-bath (Gallenkemp Gmbh) with temperature control thermostat set at $45^{\circ} \mathrm{C}$. Each animal was introduced into the chamber and then 


\section{EFFECT OF COLD AND HOT TEMPERATURES}

the temperature was gradually raised till the water-bath temperature and the animal body temperature reached $45 \pm 1^{\circ} \mathrm{C}$. After constant exposure to this temperature for $24 \mathrm{hr}$, blood samples were collected.

\subsection{Analysis of plasma}

The following components were determined quantitatively in the plasma collected from the three groups of U.aegyptius, using the BioMerieax Vitek (Missouri, USA) kits. Total protein following the principal of Biuret reaction according to Peters (1968); albumin according to Drupt et al. (1974); triglyceride according to Fossati and Prencipe (1982); cholesterol according to Anonymous (1989); glucose according to Tender (1969); urea according to the modified Berthelot reaction after Patton and Crouch (1977); uric acid as described by Artiss and Entwistle (1981). $\mathrm{T}_{3}$ and $\mathrm{T}_{4}$ were determined using enzyme immuno assay (EIA). Plasma globulin concentration was calculated by subtraction. Fractionation of total protein was carried-out using cellulose acetate electrophoresis (Helena Lab. Instruments Ltd. U.K), and the electropherograms were then scanned using Personal densitometer SI (Amersham Pharmacia Biotech), and the percentages of the different protein fractions were determined.

\subsection{Statistical analysis}

Analysis of Variance (ANOVA) was utilized for testing the overall effects of cooling and warming on selected blood measures. Post-hoc comparisons were conducted between pairs of means, via LSD procedure, on total protein, albumin, cholesterol, globulin, urea, uric acid, T3, and T4.

\section{Results}

\subsection{Behaviour}

U.aegyptius are known to tolerate extreme low and high temperatures (Bartholmew, 1981). The results of this study showed that when the animals were exposed to low temperature $\left(2^{\circ} \mathrm{C}\right)$, they became lethargic and immobile. No change of color was noticed during this period. At $2{ }^{\circ} \mathrm{C}$ blood circulation was very slow and the animal needed to be rubbed on the neck and back to facilitate the flow, when drawing blood. At high temperature U.aegyptius were noticed to fight for release when body temperature reached $40^{\circ} \mathrm{C}$. Defecation was observed after two hours of high temperature exposure. They started to pant when temperature crossed the $40^{\circ} \mathrm{C}$ limit. Body colouration changed from a dark tan to pale yellow at $42^{\circ} \mathrm{C}$.

\subsection{Blood components}

Table 1 shows the concentrations of plasma proteins in U.aegyptius exposed to the low and high temperatures compared to that in U.aegyptius exposed to the room temperature $\left(22^{\circ} \mathrm{C}\right)$. No significant difference was observed in plasma total proteins between animals exposed to the $2^{\circ} \mathrm{C}$ and the $22^{\circ} \mathrm{C}$, but there was a significant $(\mathrm{P}<0.05)$ increase in plasma total proteins when animals were exposed to the $45^{\circ} \mathrm{C}$. The main increase in plasma total proteins at the $45^{\circ} \mathrm{C}$ was due to an increase in albumin and $\alpha$ 1-globulin fractions. Plasma albumin and the albumin/globulin ratio were significantly $(\mathrm{P}<0.05)$ lower in animals exposed to the $2^{\circ} \mathrm{C}$ (Table 2$)$.

The electrophoretic separation of plasma proteins indicates that there was a significant decrease $(\mathrm{P}<0.05)$ in the $\alpha 2$-globulin fraction when animals were exposed to either the $2^{\circ} \mathrm{C}$ or the $45^{\circ} \mathrm{C}$. No significant change was observed in the percentages of the $\beta$ and $\gamma$-globulin fractions when animals were exposed to the three different temperatures (Table 2).

The mean concentrations of some plasma constituents in U.aegyptius exposed to the three different temperatures are presented in Table 1. There was no significant $(\mathrm{P}>0.05)$ difference in the concentrations of plasma triglycerides in U.aegyptius exposed to the different temperatures (Table2). Plasma cholesterol concentrations in animals exposed to the $22^{\circ} \mathrm{C}$ and the $45^{\circ} \mathrm{C}$ were 


\section{A.A. EL-BANNA and A.M. AL-JOHANY}

about the same, but a significant $(\mathrm{P}<0.05)$ decrease in cholesterol concentration was found in animals exposed to the $2^{\circ} \mathrm{C}$ (Table 3). The mean plasma glucose concentration in U.aegyptius at room temperature $\left(22^{\circ} \mathrm{C}\right)$ was significantly $(\mathrm{P}<0.05)$ decreased in animals exposed to the $2{ }^{\circ} \mathrm{C}$, and was significantly $(\mathrm{P}<0.05)$ increased in animals exposed to the $45^{\circ} \mathrm{C}$ (Table 3 ).

Table 1: Mean concentration of plasma proteins in U.aegyptiuss exposed to low, Room and high temperature.

\begin{tabular}{|l|c|c|c|}
\hline \multirow{2}{*}{\multicolumn{1}{|c|}{ Measure }} & \multicolumn{3}{|c|}{ Temperature } \\
\cline { 2 - 4 } & Cold $\left(2^{\circ} \mathrm{C}\right)$ & Room $\left(22^{\circ} \mathrm{C}\right)$ & Warm $\left(45^{\circ} \mathrm{C}\right)$ \\
\hline Total Protein $(\mathrm{g} / \mathrm{dl})$ & $2.53 \pm 0.27$ & $2.90 \pm 0.15$ & $3.65 \pm 0.17$ \\
\hline Albumin $(\mathrm{g} / \mathrm{dl})$ & $0.98 \pm 0.09$ & $1.27 \pm 0.10$ & $1.67 \pm 0.09$ \\
\hline Globulin $(\mathrm{g} / \mathrm{dl})$ & $1.98 \pm 0.30$ & $1.74 \pm 0.19$ & $2.30 \pm 1.10$ \\
\hline Albumin/Globulin ratio & $0.49 \pm 0.06$ & $0.72 \pm 0.05$ & $0.73 \pm 0.05$ \\
\hline Triglyceride $(\mathrm{mg} / \mathrm{dl})$ & $19.2 \pm 3.5$ & $18.3 \pm 4.0$ & $22.5 \pm 1.8$ \\
\hline Cholesterol $(\mathrm{mg} / \mathrm{dl})$ & $104.7 \pm 15.9$ & $234.3 \pm 28.3$ & $226.4 \pm 28.4$ \\
\hline Glucose $(\mathrm{mg} / \mathrm{dl})$ & $206 \pm 8.8$ & $281.9 \pm 16.8$ & $358.0 \pm 12.8$ \\
\hline Urea $(\mathrm{mg} / \mathrm{dl})$ & $12.3 \pm 1.3$ & $8.8 \pm 0.5$ & $12.0 \pm 8.0$ \\
\hline Uric Acid $(\mathrm{mg} / \mathrm{dl})$ & $2.8 \pm 0.3$ & $3.1 \pm 0.4$ & $5.8 \pm 0.7$ \\
\hline T3 $(\mathrm{ng} / \mathrm{dl})$ & $7.0 \pm 0.5$ & $7.6 \pm 1.0$ & $7.6 \pm 0.8$ \\
\hline T4 $(\mu \mathrm{g} / \mathrm{dl})$ & $3.0 \pm 0.2$ & $4.1 \pm 0.4$ & $5.4 \pm 0.3$ \\
\hline
\end{tabular}

Table 2: Summary table of ANOVA conducted on Dependent Variables (measures).

\begin{tabular}{|l|l|l|l|l|l|l|}
\hline Measure & Source of Variation & SS & df & MS & $\mathbf{F}_{\text {(value) }}$ & $\mathbf{F}_{\text {(probability) }}$ \\
\hline Total Protein & Between Group & 4.32 & 2 & 2.15 & $17.21^{*}$ & 3.63 \\
& Within Group & 3.85 & 16 & 0.24 & & \\
\hline Albumin & Between Group & 1.42 & 2 & 0.71 & $12.29^{*}$ & 3.63 \\
& Within Group & 0.87 & 16 & 0.05 & & \\
\hline Globulin & Between Group & 1.03 & 2 & 0.51 & 1.54 & 3.63 \\
& Within Group & 5.32 & 16 & 0.33 & & \\
\hline Albumin / & Between Group & 0.36 & 2 & 0.18 & 2.25 & 3.63 \\
Globulin Ratio & Within Group & 1.28 & 16 & 0.08 & & \\
\hline Glucose & Between Group & 74174.67 & 2 & 37087.34 & $33.97^{*}$ & 3.63 \\
& Within Group & 17467.53 & 16 & 1091.72 & & \\
\hline Triglycerides & Between Group & 51.69 & 2 & 25.84 & .41 & 3.63 \\
& Within Group & 989.49 & 16 & 61.84 & & \\
\hline Cholesterol & Between Group & 64793.73 & 2 & 32396.86 & $7.97^{*}$ & 3.63 \\
& Within Group & 65184.06 & 16 & 4074.00 & & \\
\hline Urea & Between Group & 45.62 & 2 & 22.81 & $4.44^{*}$ & 3.63 \\
& Within Group & 82.16 & 16 & 5.14 & & \\
\hline Uric Acid & Between Group & 35.68 & 2 & 17.84 & $10.06^{*}$ & 3.63 \\
& Within Group & 28.36 & 16 & 1.77 & & \\
\hline T3 & Between Group & 1.25 & 2 & 0.62 & 0.16 & 3.63 \\
& Within Group & 60.09 & 16 & 3.75 & & \\
\hline T4 & Between Group & 18.84 & 2 & 9.42 & 1.92 & 3.63 \\
& Within Group & 78.26 & 16 & 4.89 & & \\
\hline
\end{tabular}

$* \mathrm{P}<0.05$ 


\section{EFFECT OF COLD AND HOT TEMPERATURES}

There was a significant $(\mathrm{P}<0.05)$ increase in the mean plasma urea concentration when U.aegyptius were exposed to either the $2^{\circ} \mathrm{C}$ or to the $45^{\circ} \mathrm{C}$ (Table 3). Also, there was a significant $(\mathrm{P}<0.05)$ increase in the mean plasma uric acid concentration when U.aegyptius were exposed to the $45^{\circ} \mathrm{C}$, but no change in plasma uric acid was observed in animals exposed to the $2^{\circ} \mathrm{C}$ and $22^{\circ} \mathrm{C}$ (Table 3).

Table 3: Multiple Comparisons of Differential Mean Effect Using LSD Method for only Those Variable which Were Significantly Different.

\begin{tabular}{|c|c|c|c|c|c|c|c|c|}
\hline \multicolumn{3}{|c|}{ Total Protein } & \multicolumn{3}{|c|}{ Albumin } & \multicolumn{3}{|c|}{ Glucose } \\
\hline Group & $\begin{array}{c}\text { Mean } \\
\text { Diff. }\end{array}$ & Sig. & Group & $\begin{array}{c}\text { Mean } \\
\text { Diff. }\end{array}$ & Sig. & Group & $\begin{array}{l}\text { Mean } \\
\text { Diff. }\end{array}$ & Sig. \\
\hline $\begin{array}{ll}\text { LT } & \text { RT } \\
& \text { HT } \\
\end{array}$ & $\begin{array}{l}-0.5333^{*} \\
-1.2905^{*}\end{array}$ & $\begin{array}{l}0.034 \\
0.000\end{array}$ & $\begin{array}{ll}\text { LT } & \text { RT } \\
& \text { HT } \\
\end{array}$ & $\begin{array}{l}-0.4333^{*} \\
-0.7988^{*}\end{array}$ & $\begin{array}{l}0.033 \\
0.000\end{array}$ & $\begin{array}{ll}\text { LT } & \text { RT } \\
& \text { HT } \\
\end{array}$ & $\begin{array}{l}-74.700^{*} \\
-151.328^{*}\end{array}$ & $\begin{array}{l}0.001 \\
0.000\end{array}$ \\
\hline $\begin{array}{ll}\text { RT } & \text { LT } \\
\text { HT }\end{array}$ & $\begin{array}{l}0.5333^{*} \\
-0.7571 *\end{array}$ & $\begin{array}{l}0.034 \\
0.004\end{array}$ & $\begin{array}{ll}\text { RT } & \text { LT } \\
& \text { HT }\end{array}$ & $\begin{array}{l}-0.4333^{*} \\
-0.3655\end{array}$ & $\begin{array}{l}0.033 \\
0.058\end{array}$ & $\begin{array}{ll}\text { RT } & \text { LT } \\
& \text { HT }\end{array}$ & $\begin{array}{l}74.700^{*} \\
-76.628^{*}\end{array}$ & $\begin{array}{l}0.001 \\
0.001\end{array}$ \\
\hline $\begin{array}{cc}\text { HT } & \text { LT } \\
& \text { RT }\end{array}$ & $\begin{array}{l}1.2905^{*} \\
0.7571^{*}\end{array}$ & $\begin{array}{l}0.000 \\
0.004\end{array}$ & $\begin{array}{ll}\text { HT } & \text { LT } \\
& \text { RT }\end{array}$ & $\begin{array}{l}0.7988^{*} \\
0.3655\end{array}$ & $\begin{array}{l}0.000 \\
0.058\end{array}$ & $\begin{aligned} \text { HT LT } \\
\text { RT }\end{aligned}$ & $\begin{array}{l}151.328^{*} \\
76.628^{*}\end{array}$ & $\begin{array}{l}0.000 \\
0.001\end{array}$ \\
\hline
\end{tabular}

\begin{tabular}{|c|c|c|c|c|c|}
\hline \multicolumn{3}{|c|}{ Cholesterol } & \multicolumn{3}{|c|}{ Uric Acid } \\
\hline Group & $\begin{array}{l}\text { Mean } \\
\text { Diff. }\end{array}$ & Sig. & Group & $\begin{array}{l}\text { Mean } \\
\text { Diff. }\end{array}$ & Sig. \\
\hline $\begin{array}{ll}\text { LT } & \text { RT } \\
& \text { HT }\end{array}$ & $\begin{array}{l}-129.746^{*} \\
-121.728^{*}\end{array}$ & $\begin{array}{l}0.003 \\
0.003\end{array}$ & $\begin{array}{ll}\text { LT } & \text { RT } \\
& \text { HT }\end{array}$ & $\begin{array}{c}-0.2667 \\
-2.9657^{*}\end{array}$ & $\begin{array}{l}0.733 \\
0.001\end{array}$ \\
\hline $\begin{array}{ll}\text { RT } & \text { LT } \\
& \text { HT }\end{array}$ & $\begin{array}{c}129.746^{*} \\
8.018\end{array}$ & $\begin{array}{l}0.003 \\
0.824\end{array}$ & $\begin{array}{ll}\text { RT } & \text { LT } \\
& \text { HT }\end{array}$ & $\begin{array}{c}0.2667 \\
-2.6990^{*}\end{array}$ & $\begin{array}{l}0.733 \\
0.002\end{array}$ \\
\hline $\begin{array}{ll}\text { HT } & \text { LT } \\
& \text { RT }\end{array}$ & $\begin{array}{c}121.728^{*} \\
-8.018\end{array}$ & $\begin{array}{l}0.003 \\
0.824\end{array}$ & $\begin{array}{ll}\text { HT } & \text { LT } \\
& \text { RT }\end{array}$ & $\begin{array}{c}2.9657^{*} \\
2.6990\end{array}$ & $\begin{array}{l}0.001 \\
0.002\end{array}$ \\
\hline
\end{tabular}

*The mean difference is significant at the 0.05 level.

The mean plasma $T_{3}$ and $T_{4}$ concentrations were not significantly different among animals exposed to the three different temperatures, although $\mathrm{T}_{4}$ concentrations were somewhat higher at the $22^{\circ} \mathrm{C}$ and the $45^{\circ} \mathrm{C}$ (Table 2).

\section{Discussion}

In their natural habitat, U.aegyptius are exposed to low or high temperatures. In many instances they continue activity while air temperature is around $40^{\circ} \mathrm{C}$ and above (Louw and Gideon, 1993). They remain in their burrows when surface temperature falls below $10^{\circ} \mathrm{C}$. They are not true hibernators; they may come out during winter when it is warm enough like many other lizards. They usually become active when temperature reaches $30^{\circ} \mathrm{C}$, and when temperatures reache above $40^{\circ} \mathrm{C}$ they seek shelter in their deep underground burrows.

In our study, a significant decrease in blood glucose and cholesterol levels were found in U.aegyptius exposed to $2^{\circ} \mathrm{C}$ for about two days. This was also associated with a significant decrease in albumin fraction of the plasma proteins, and with a significant increase in the levels of plasma urea. On the other hand, a significant increase in blood glucose, as well as a significant increase in plasma total proteins, urea and uric acid were found in U.aegyptius exposed to $45^{\circ} \mathrm{C}$ for 24 hours. To adjust for changes in environmental temperature many ectothermic vertebrates 


\section{A.A. EL-BANNA and A.M. AL-JOHANY}

lower the selected body temperature during winter (Hazel and Prosser, 1974; Case, 1976). Ectotherms exposed to higher temperatures attempt to regulate their body temperature below the air temperature (Huey, 1982). These alterations in the selected body temperature lead to blood biochemical changes. Such modification seem to be achieved by metabolic changes which lead to changes in the composition of blood and tissues (White and Somero, 1982; Geiser et al., 1992). Therefore, measurements of blood composition are commonly used to assess the way in which the environment affects the physiology of animals.
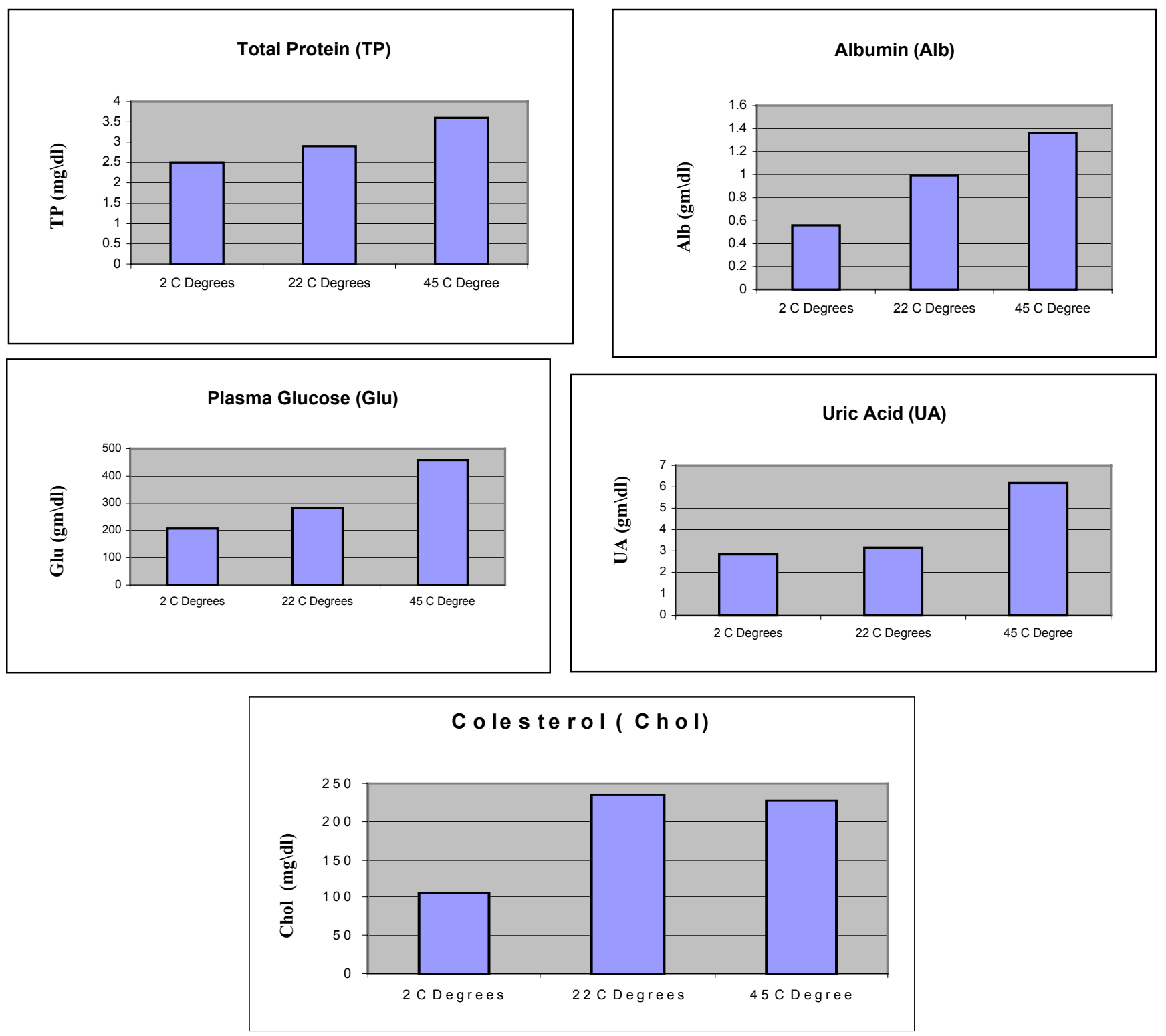

Figure 1. Plot of the changes in total protein (TP), Albumin (Alb), Glucose (Glu), uric acid (UA), and cholesterol (Chol) among variation in environmental temperature.

When lizard species normaly encounter temperatures close to or below $0^{\circ} \mathrm{C}$, they have exceptionally high survival rates (Geiser and Firth, 1992). These lizards survive exposure to subfreezing temperatures by supercooling, i.e., by remaining unfrozen at temperatures below the equilibrium crystallization temperature of body fluids (Grenot and Heulin, 1990). Also, some lizards are freeze-tolerant (Storey and Storey, 1992; Costanzo et al., 1995). Ectotherms can counteract a potentially freezing ambient temperature by increasing the osmotic concentration of 


\section{EFFECT OF COLD AND HOT TEMPERATURES}

their body fluids so that its freezing point is depressed below the ambient temperature (Withers, 1992). Some ectotherms accumulate high concentration of specific solutes to depress their freezing point; these solutes are typically sugar, such as glucose or sugar alcohols. Their low molecular weight maximizes the freezing point depression per mass of solute (Withers, 1992; Lee and Costanzo, 1993). These sugars apparently have cryoprotectant effect, and they protect membranes and enzymes against cold denaturation and cold shock injury. It is important in these animals to avoid the freezing of their intracellular fluids, since intracellular ice crystals apparently destroy the integrity of intracullar membranes and organelles. In contrast, extracellular freezing does not disrupt essential cell structures and is not lethal, at least to the freeze-tolerant species (Withers, 1992; Lemos-Espinal and Ballinger, 1992). The decrease in blood could reflect a shift of glucose from the blood (extracellular fluid) to the intracellular fluids, probably through increasing cellular uptake of glucose, in anticipation of potential freezing ambient temperature. In doing that, the animals guard against intracellular freezing by depressing intracellular freezing point. The accumulation of the putative cryoprotectant glucose in tissues of lizards subjected to freeze tolerance trials had been reported (Costanzo et al. 1995).

The mean blood cholesterol level in U.aegyptius at room temperature $(234.3 \pm 28.3 \mathrm{mg} / \mathrm{dl})$ is relatively higher than that in many mammalian species (Al-Tuwaijri, 1987). Also, cholesterol content in U.aegyptius's tissues is more than twice the cholesterol content of camel, lamb and cattle tissues (Abu-Tarboush et al. 1996). Cholesterol could also have cryoprotectant effect in lizards exposed to low temperatures, and the changes in blood cholesterol level observed in the present study may indicate a role for cholesterol in thermoregulation. Changes in the lipid composition of tissues and cell membranes are apparently required in order to maintain normal function at the lower body temperatures (Bauwens, 1981).

Lizards exposed to high temperature try to reduce their body temperature below the air temperature, and this strategy of thermoregulation can only be accomplished by evaporative cooling. Evaporation of water can dissipate a considerable amount of heat and lower the temperature (Withers, 1992). Relatively waterproof terrestrial animals are generally able to enhance evaporative cooling by markedly increasing their cutaneous or respiratory water loss. The lizard Dipsosaurus totally dissipates its metabolic heat production by panting at air temperature more than $40^{\circ} \mathrm{C}$, and the large agamid lizard Amphibolurus can reduce its body temperature about $3.2^{\circ} \mathrm{C}$ below air temperature of $43^{\circ} \mathrm{C}$, and the chuckwalla lizard Sauromalus obseus can considerably lower its body and brain temperatures by evaporative cooling by panting (Withers, 1992). In this study evoparative water loss (EWL) was not measured. However, we observed, particularly because of the increased panting, that the reduction in plasma volume could be the reason for the increased concentrations of plasma glucose, total proteins, urea and uric acid observed in U.aegyptius exposed to the $45^{\circ} \mathrm{C}$. During dehydration, animals show elevated concentrations of osmolytes and proteins in their blood (Dunlap, 1995). The increased plasma glucose concentration in U.aegyptius exposed to the higher temperature could also reflect a decrease in glucose uptake by tissues in order to avoid excess intracellular glucose breakdown and energy production, and excess heat load.

Lizards exposed to high temperature can also rely on biochemical adaptations for tolerance of high body temperature. Heat stress has been shown to induce the synthesis of a family of proteins, the so-called heat shock proteins (HSPs) in cells of a wide spectrum of ecologically different lizard species (Ulmasov et al. 1992; Feder and Hofmann, 1998; Zatsepina et al. 2000). The level of HSPs were found to be higher in desert species than in the non-desert species (Zatsepina et al. 2000), and the induction and active synthesis of HSPs occurs within a temperature interval normal to the species (Ulmasov et al. 1992). HSPs play a key role in the cellular response to heat shock by maintaining the native state and proper folding of cellular proteins during physiological stress and by facilitating the restoration of cellular functions (Morimoto, 1993; Morimoto, et al., 1994). The expression of the HSP gene is tightly regulated to ensure that the response is proportional to the level of heat stress, and then repressed and terminated when normal physiological conditions recur (Lindquist, 1986). We did not measure the synthesis of HSPs in the present study, but these 


\section{A.A. EL-BANNA and A.M. AL-JOHANY}

proteins can be synthesized, particularly by liver cells, within 1 to $2 \mathrm{hrs}$ of exposure to the high temperature, and in desert lizards, the temperature range of induction and continuing synthesis of HSPs was reported to be $36-50^{\circ} \mathrm{C}$ (Ulmasov, et al., 1992). The changes in plasma protein and protein fractions observed in U.aegyptius exposed to the $45^{\circ} \mathrm{C}$ in the present study could reflect induction and synthesis of HSPs.

U.aegyptius exposed to different temperatures in the present study showed no changes in plasma levels of the thyroid hormones $\mathrm{T}_{3}$ and $\mathrm{T}_{4}$. It is not certain whether the thyroid hormones have a direct and immediate role in thermoregulation in lizards. Sinha and Choubey (1981) reported that the thyroid gland of the Indian spiny tailed, U. harrdwickii, lizard appeared most active when the environmental temperature was high. When the temperature was low, the activity of thyroid gland was decreased. These authors also noted a reduction in thyroid activity in September. They did not reach a final conclusion because they found a parallel relation to the gonadal cycle.

Based on the results of the present study, it can be concluded that behavioral, physiological, and biochemical adjustments are altered in response to environmental temperature changes. However, the exact biological mechanisms are species specific in lizard populations. The physiological and biochemical control of thermoregulation in reptiles, and in U.aegyptius in particular, need more investigations, and as indicated by Grigg and Seebacher (1999) that the control of thermoregulation in reptiles is more complex than has been previously recognized.

\section{Acknowledgements}

We wish to thank Dr. S. Haffor for reviewing the manuscript. Mr. Awni El-Gazawi and Mr. M.Y. AbdulRawoof are also thanked for their technical help in the laboratory.

\section{References}

ARNOLD, E.N. 1986. A key and annotated checklist to the lizards and amphisbaenians of Arabia. Fauna of Saudi Arabia 8: 335-435.

ARTISS, J.D. and ENTWISTLE, W.M. 1981.The application of a sensitive uricase-peroxidase couple reaction to a centrifugal fast analyser for the determination of uric acid. Clin Chim Acta.; 116(3):301-309.

ABU-TARBOUSH, H. M., AL-JOHANY, A.M. and AL-SADOON, M.K. 1996. Proximate composition and fatty acids and cholestrol content of U.aegyptius's meat (Uromastyx aegyptius Blanford 1874) at the end of winter and during spring. Journal of College of Agriculture of King Saud University. 8 : 79-92.

AL-TUWAIJRI, A.S. 1987. Standard Biological Data. Human and Experimental animals. King Saud University Press, Riyadh, Saudi Arabia.

ANONYMOUS 1989. The French consensus on cholesterol and dyslipoproteinemias. Administration Council of ARCOL. Rev. Prat.; 39(11): 972-974. Review. French.

BARTHOLMEW, G.A. 1981. Physiological thermoregulation. In Biology of the reptilia. Vol. 12, Physiological ecology eds C. Gans and F. H. Pough). Academic press, New York. pp. 167-212

BAUWENS, D. 1981. Survivorship during hibernation in the European common lizard, Lacerta vivipara. Copeia 1981: 741-744.

CASE, T. J. 1976. Seasonal aspect of thermoregulatory behavior in the chuckawalla, Sauromalus obesus (Reptilia, Lacertilia, Iguanidae). Journal of Herpetology 10: 85-95.

COSSINS, A. R., and BOWLER, K. 1987. Temperature biology of animals. Chapman \& Hall, London.

COSTANZO, J.P., GRENOT, C. and LEE, R.E.Jr. 1995. Supercooling ice inoculation and freeze tolerance in the European common lizard, Lacerta vivipara. Journal of Comparative Physiology B, 165: 238-244. 


\section{EFFECT OF COLD AND HOT TEMPERATURES}

DRUPT, F., PARIS, M., FRYDMAN, A., LECLERC, M. 1974. Plasma albumin assay by bromocresol green method: application to different automatic apparatus. Ann Pharm Fr. 32(5):249-256. French.

DUNLAP, K.D. 1995. External and internal influences on indices of physiological stress: II. Seasonal and size related variations in blood composition in free-living lizards, Sceloporus occidentalis. Journal of Experimental Zoology 272: 85-94.

FEDER, M.E. and HOFMANN, G.E. (1998). Evolutionary and ecological physiology of heatshock proteins and the heat-shock response: comparative bibliography. Annual Review of Physiology 61: 243-282.

FIRTH, B. T. and BELAN, I. 1998. Daily and seasonal rhythms in selected body temperature in the Australian lizard Tiliqua rugosa (Scincidae): Field and laboratory observations . Physiological Zoology 71: 303-311.

FOSSATI, P. and PRENCIPE, L. 1982 Plasma triglycerides determined colorimetrically with an enzyme that produces hydrogen peroxide. Clinical Chemistry Oct; 28(10):2077-80.

GEISER, F., FIRTH, B.T., and SIGMOUR, R. S. 1992. Poly-unsaturated dietary lipids lower the selected body temperature of a lizard. Journal of Comparative Physiology B, 162: 1-4.

GRENOT, C., and HEULIN, B. 1990. Sur la palasticite ecophysiologique du lezard vivipare, Lacerta vivipara (Reptilia, Lacertidae). Bulletin of Society for Herpetology, France. 54: 1-22.

GRIGG, G.C. and SEEBACHER, F. 1999. Field test of a paradigm: hysteresis of heart rate in thermoregulation by a free-ranging lizard (Pogona barbata). Proceeding of Royal Society London. B. Biological Science 266: 1291-1297.

HAZEL, J. R. and PROSSER, C.L. 1974. Molecular mechanisms of temperature compensation in poikilotherms. Physiology Review 54: 620-677.

HEW, C.L., SCOTT, G. K. and DAVIES, P.L. 1986. Molecular biology of antifreeze. In Living in the cold: Physiological and biochemical adaptations eds H. C. Heller., X.J. Musacchia and L.C.H. Wang Elsevier, New York. pp. 117-123.

HUEY, R.B. 1982. Temperature, physiology and the ecology of reptiles. In Biology of the reptilia Vol. 12, Physiological ecology ed. F.H. Pough. Academic Press, London. pp. 26-90.

LEE, R.E., and COSTANZO, J.P. 1993. Integrated physiological responses promoting anuran freeze tolerance. In Life in the cold III: ecological, physiological and molecular mechanisms eds C. Carey et. al. Westview Press, Boulder, Colarado. pp. 501-510.

LEMOS-ESPINAL, J. A., and BALLINGER, R.E. 1992. Observations on the tolerance to freezing by the lizard, Sceloporus grammicus, from Iztaccihuattl volcano, Mexico. Herpetological Review 23: 8-9.

LINDQUIST, S. 1986. The heat shock response. Annual Review of Biochemistry. 55:1151-1191.

LOUW, G.N. and GIDEON, N. 1993. Physiological animal ecology. John Wiley \& Sons Inc. New York.

MORIMOTO, R.I. 1993. Cells in stress: transcriptional activation of heat shock genes. Science 259: $1409-1410$.

MORIMOTO, R.I., TISSIERES, A. and GEORGOPOLOUS, C. 1994. The biology of heat shock proteins and molecular chaperones. Cold Spring Harbor Laboratory Press, Plainview, NY.

PATTON, C. J. and CROUCH, S.R. 1977. Spectrophotometric and kinetic investigation of Berthelot reaction for the determination of ammonia. Anal. Chem.; 49 (1-4): 464-469.

PETERS, T. Jr. 1968. Proposals for standardization of total protein assays. Clinical Chemistry Dec; 14(12):1147-59.

SINHA, A.K. and CHOUBEY, B.J. 1981. Seasonal changes in the thyroid gland of Indian spiny tailed, sand lizard, Uromastix hardwickii (Gray) male. Z. Mikrosk. Anat. Forsch. 95:72-80.

STOREY, K.B. and STOREY, J. M. 1992. Natural freeze tolerance in ectothermic vertebrates. Annual Review of Physiology 54: 619-637.

TRINDER, P. 1969. Determination of blood glucose using 4-amino phenazone as oxygen acceptor. Journal of Clinical Patholology.; Mar; 22(2):246. 
ULMASOV, K.A., SHAMMAKOV, S., KARAEV, K. and EVEGENEV, M.B. 1992. Heat shock proteins and thermoresistance in lizards. Proceeding of National Academy of Science. 89: 1666-1670.

WHITE, F.N., and SOMERO, G. 1982. Acid-base regulation and phospholipid adaptation to temperature: Time course and physiological significance of modifying the milieu for protein function. Physiology Review 62: 40-90.

WITHERS, P. C. 1992. Comparative Animal Physiology. Saunders College Publishing, New York. ZATESPINA, O.G., ULMASOV, K.A., BERESTEN, S.F., MOLODTSOV, V.B., RYBTSOV, S.A. and EVEGENEV, M.B. 2000. Thermotolerant desert lizards characteristically differ in terms of heat-shock system regulation. Journal of Experimental Biology, 203: 1017-1025.

Received 18 May 2002

Accepted 19 April 2003 